\title{
Laboratory and in-situ studies on larval development and swimming performance of Pacific herring Clupea harengus pallasi
}

\author{
H. vON WESTERNHAgEN \& H. ROSENTHAL \\ Biologische Anstalt Helgoland (Zentrale); Palmaille 9, \\ D-2000 Hamburg 50, Federal Republic of Germany
}

\begin{abstract}
Pacific herring Clupea harengus pallasi larvae were caught alive in Departure Bay, B.C., Canada, after being attracted towards light. Growth of larvae was observed during a 5-week period. Larval total length (measured in live anaesthetized specimens) during this period increased from $8 \mathrm{~mm}$ to $28 \mathrm{~mm}$. Development of condition factor was observed through the yolk-sac stage until the early post yolk-sac stage. Condition factor decreased linearly in yolk-sac larvae and increased in post yolksac specimens. Swimming performance of Pacific herring larvae in their natural habitat was studied during the day by means of direct observations and compared with laboratory investigations conducted with "wild" and laboratory-reared larvae. In the laboratory (black 35-cm diameter tanks, $10^{\circ} \mathrm{C}$ ) "wild" larvae swam more slowly and were less active (measured as \% active time) than in their natural habitat. Laboratory reared larvae showed depressed activity when compared with "wild" larvae observed in the sea. This phenomenon was attributed to deprivation of stimuli in confined containers which might have some bearing on the validity of data gained from controlled ecosystem experiments.
\end{abstract}

\section{INTRODUCTION}

Due to their importance for larval survival, growth and swimming performance of herring larvae have been well investigated. Growth of larvae has been studied by numerous authors in the Atlantic herring (e.g. Marshall et al., 1937; Jensen, 1950; Schnack, 1972; Titmus et al., 1978) as well as in the Pacific herring (McHugh, 1940; Stevenson, 1962; Baraclough, 1967). In all cases growth of larvae was gained from preserved material trying to take into account different rates of shrinkage determined more or less from the authors' estimate. Thus estimates for shrinkage after fixation range from $2 \%$ (Stevenson, 1962) up to $20 \%$ for sea-caught larvae (Blaxter, 1971).

Information on swimming performance of herring larvae is only available through laboratory studies conducted with the larvae of the Atlantic herring by Bückmann et al. (1953) and more recently by Rosenthal (1968) and Blaxter \& Staines (1971). Direct observations from the natural habitat are wanting because they are difficult to obtain.

The present study tries to furnish some information on Pacific herring larvae observed unter in situ and laboratory conditions relating to some morphological data obtained from living specimens. 


\section{MATERIAL AND METHODS}

During April and May (1974) Pacific herring larvae were studied in the laboratory and in the field at the pier of the Pacific Biological Station, Nanaimo, Canada. At night larvae were attracted using a $300-\mathrm{W}$ light bulb bearing a white reflector, suspended about $5 \mathrm{~cm}$ above the water surface. Larvae were caught with pails and transferred to the laboratory where they were immediately anaesthetized (MS 222); total length and otic capsule diameter were measured under the microscope. For activity measurements other individuals were immediately introduced into experimental containers.

For in situ observations larvae were studied in the upper $10 \mathrm{~cm}$ of the surface in Departure Bay by direct observations of single larvae from $09.00-15.00$, while the authors were lying on the docks of the mooring facilities of the Nanaimo research vessels. The paths of individual larvae were traced with the help of a metre stick, which was moved with the current for up to $3 \mathrm{~min}$. Distance covered by the larvae was estimated by one author only throughout all experiments. The duration of activities and passive drifting was recorded. After termination of the observation period, the individuals were caught with a long large-bore pipette and transferred to the laboratory for length and weight determinations.

Activity measurements in the laboratory were conducted with wild and laboratoryreared larvae in black circular tanks (diameter $35 \mathrm{~cm}$ ) filled with sea water up to a height of $10 \mathrm{~cm}$, under $60-\mathrm{W}$ fluorescent lights at $10^{\circ} \mathrm{C}$. Paths of single larvae were followed and the distance travelled estimated by an overhead calibrated grid. Duration of active and passive phases was recorded.

All observed larvae were anaesthetized and measured under a microscope for total length and otic capsule diameter. After rinsing in distilled water larvae were mounted on silicon coated slides and stored for dry weight determination.

\section{RESULTS}

\section{General observations}

Although the larvae-attracting light bulb was working continuously from April 12th until May 5th every night, larvae only occurred under the light on certain days (Fig. 1). Aside from a few windy nights with modest wave action from April 23rd until April 26th, all nights were calm and the water was clear. When larvae appeared, they tended to concentrate under the light at the slack of tide. With the outgoing tide the larvae disappeared with the current.

During the day yolk-sac larvae, which usually occurred in patches of differing dimensions, were more or less evenly distributed at or just below the water surface; individual distances varied from 1.0 to $5.0 \mathrm{~cm}$. Larger larvae $(>22 \mathrm{~mm})$ remained in the deeper layers 50 to $100 \mathrm{~cm}$ in depth. When the herring larvae were concentrated under the light, sticklebacks (Gasterosteus aculeatus) and young salmon would congregate and feed heavily on them. As described by Westernhagen (1976) a predatory hyperiid amphipod (Hyperoche medusarum) preyed on the herring larvae. 

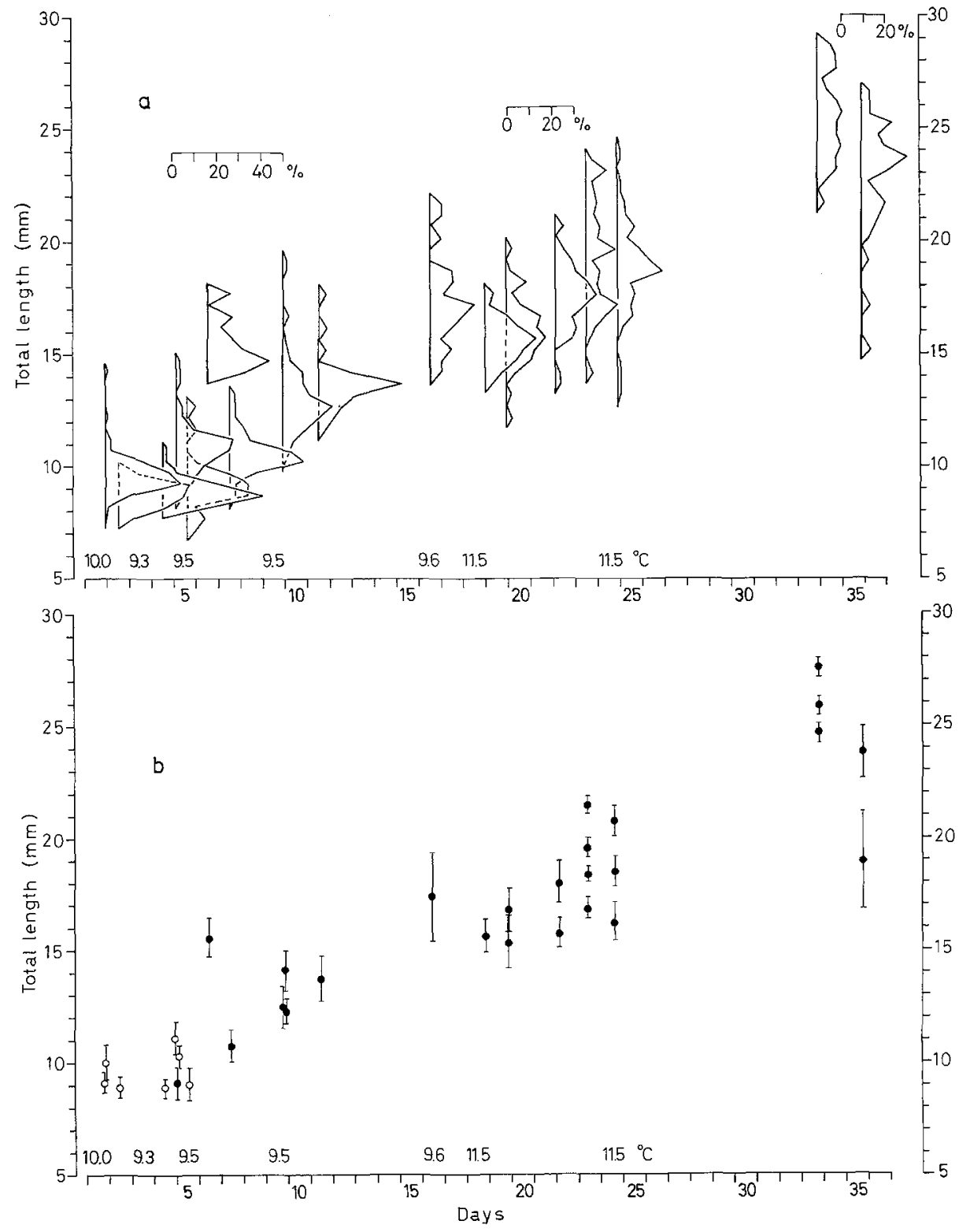

Fig. 1: Length distribution $\left(\mathrm{T}_{\mathrm{I}}\right.$ ) (a: \% frequency curves) of Pacific herring larvae caught in Departure Bay, Canada, during April and May 1974. The lower part (b) indicates means derived from catches separated on probability paper. o: yolk sac larvae; ${ }^{\circ} \mathrm{C}$ : water temperature at the surface 


\section{Growth}

Figure 1 depicts herring larvae growth in Departure Bay 1974, using percent frequency curves for the different catches. The spread of the length composition of the catches varies with time (Fig. 1a) showing unimodal curves in April and bi- or polymodal distribution in May. In Figure $1 \mathrm{~b}$ single catches are, where possible, separated by the use of probability paper for the graphical analysis of polymodal frequency distributions as described by Harding (1949) and employed by Hourston (1958) and Das (1972). As a result of multiple spawnings and/or hatchings in or near Departure Bay the analyses show the existence of several distinct length groups of larvae within one catch.

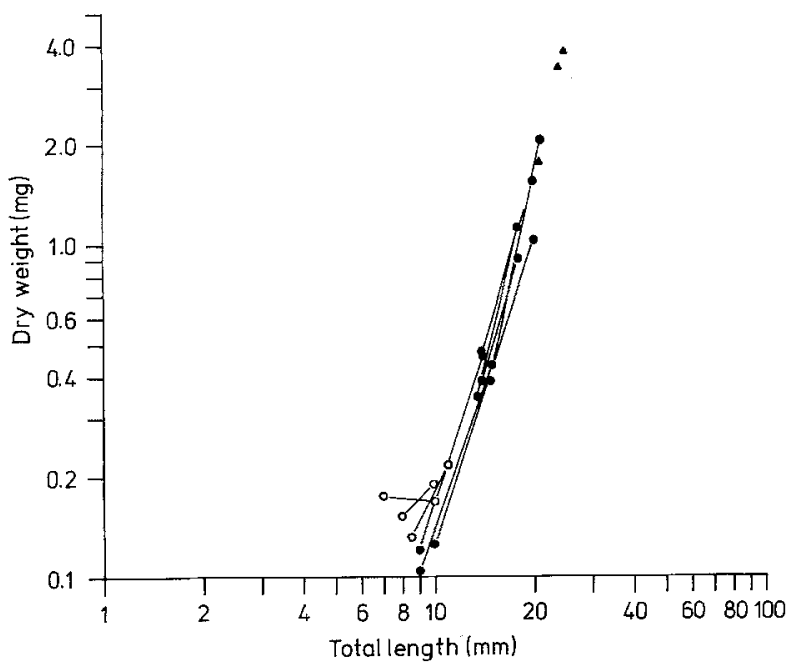

Fig. 2: Calculated length/weight relationship of Pacific herring larvae caught in Departure Bay, Canada, 1974. Each line representing one catch. Total $n=456$; o: yolk sac larvae; $\boldsymbol{\Delta}$ : data from 1976

The invasion of larval populations from other spawning grounds (or earlier spawnings) into the Bay is apparent from the occurrence of relatively large larvae on April 16th, which, judging from their total lengths, were about 6 days older than the larvae collected earlier in the day. Major spawning grounds existed a few miles north of Departure Bay.

From the data presented in Figure 1 we calculated the daily larval growth in Departure Bay to be around $0.46 \mathrm{~mm}$ (as calculated from the means in Fig. 1b, $r=0.92$, mean surface temperature $10.1^{\circ} \mathrm{C}$ ).

Weight of yolk sac and post yolk-sac larvae (as dry weight) ranged from slightly above $0.1 \mathrm{mg}$ in $9 \mathrm{~mm}$ larvae to more than $2 \mathrm{mg}$ in $21 \mathrm{~mm}$ larvae (Fig. 2). Length/weight relationship in yolk-sac larvae differed considerably from that of post yolk-sac larvae, due to the yolk being absorbed during larval development. Therefore condition factors of yolksac and post yolk-sac larvae, frequently used in the assessment of the state of condition of larvae (Hempel \& Blaxter, 1963; Blaxter 1971; Vilela \& Zijlstra, 1971) also vary considerably, and linear regressions describing the development of condition factors with length showed a negative slope for yolk-sac larvae $\left(y=0.0748-0.0057 x ; r_{205}=-0.76\right)$. In post 


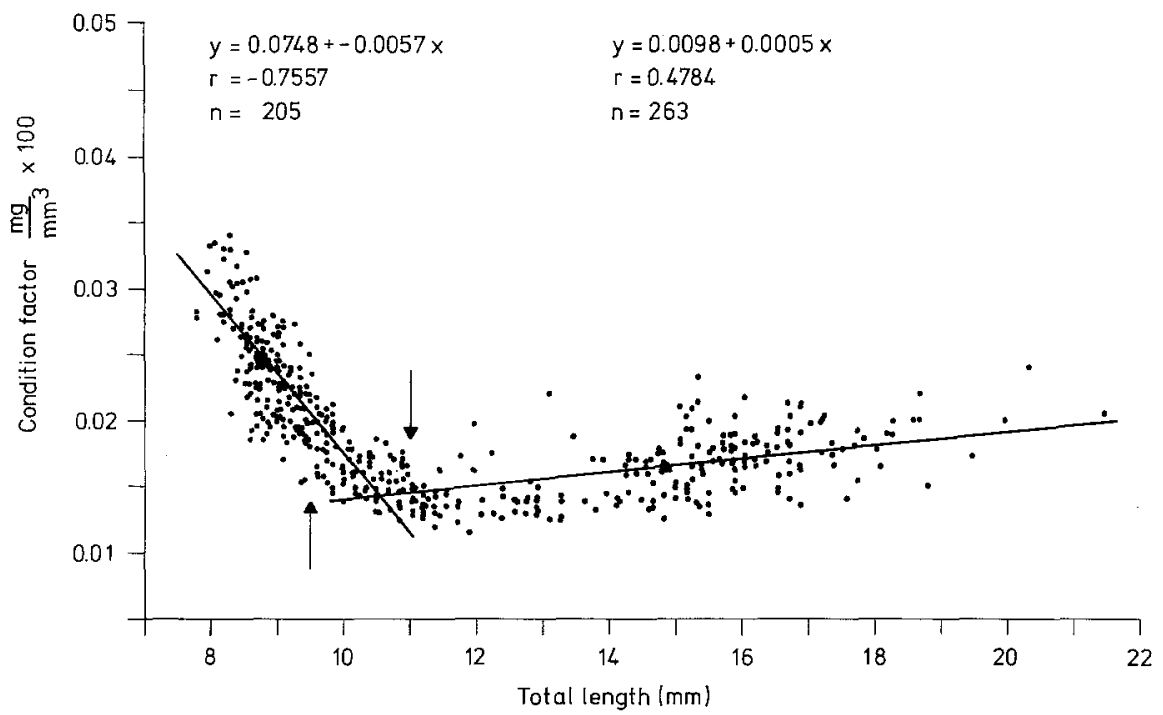

Fig. 3: Change of condition factor with growth of Pacific herring larvae from Departure Bay, Canada. Arrows indicate range of overlapping of yolk-sac and post yolk-sac larvae

yolk-sac larvae condition factors increased linearly with length $(y=0.0098+0.00045 x$; $r_{263}=0.51$ ). Between 9.5 and $11.0 \mathrm{~mm}$ there was a range where the condition factors of late yolk-sac larvae and early post yolk-sac larvae overlapped (Fig. 3).

Within the range of the post yolk-sac larvae collected during our study $(9.5-21.5 \mathrm{~mm})$ increase of condition factor was linear with increase of total length. This is true also when considering development in larger larvae which we were able to collect in 1976, but did not include in this presentation.

\section{Swimming performance}

Data on swimming perfomance are summarized in Table 1. Cruising speed of undisturbed larvae in the natural habitat near the water surface varied greatly from around

Table 1

Swimming speed, time active (\%), and number of swimming bursts/min of "wild" (a) and laboratory reared (b) Pacific herring larvae observed under natural (c) and laboratory (d) (35-cm black tank) conditions. Water temperatur ca. $9.5^{\circ} \mathrm{C}$; ": "wild" larvae kept two days in the laboratory before testing; TL: total length; number of individuals tested given in brackets

\begin{tabular}{|c|c|c|c|c|c|}
\hline \multicolumn{2}{|c|}{$\begin{array}{l}\text { Larval } \\
\text { type }\end{array}$} & $\begin{array}{c}\mathrm{T}_{\mathrm{L}} \\
(\mathrm{mm})\end{array}$ & $\begin{array}{l}\text { Number of } \\
\text { swimming } \\
\text { bursts/min }\end{array}$ & $\begin{array}{l}\text { Swimming } \\
\text { speed } \\
(\mathrm{cm} / \mathrm{sec})\end{array}$ & $\begin{array}{l}\text { Time } \\
\text { active } \\
(\%)\end{array}$ \\
\hline a & $\mathrm{c}$ & $7.4-12.5$ & $17.6 \pm 6.7(44)$ & $1.6 \pm 0.5(100)$ & $50.4 \pm 15.6(44)$ \\
\hline a & d & $8.4-10.7$ & $19.1 \pm 5.3(21)$ & $1.6 \pm 0.4(17)$ & $39.4 \pm 11.2(32)$ \\
\hline a & d & $9.5-10.9$ & $* 29.9 \pm 11.1(11)$ & & \\
\hline $\mathrm{b}$ & d & $8.4-10.3$ & $26.1 \pm 5.4(48)$ & $0.9 \pm 0.5(15)$ & $29.8 \pm 9.2(40)$ \\
\hline
\end{tabular}




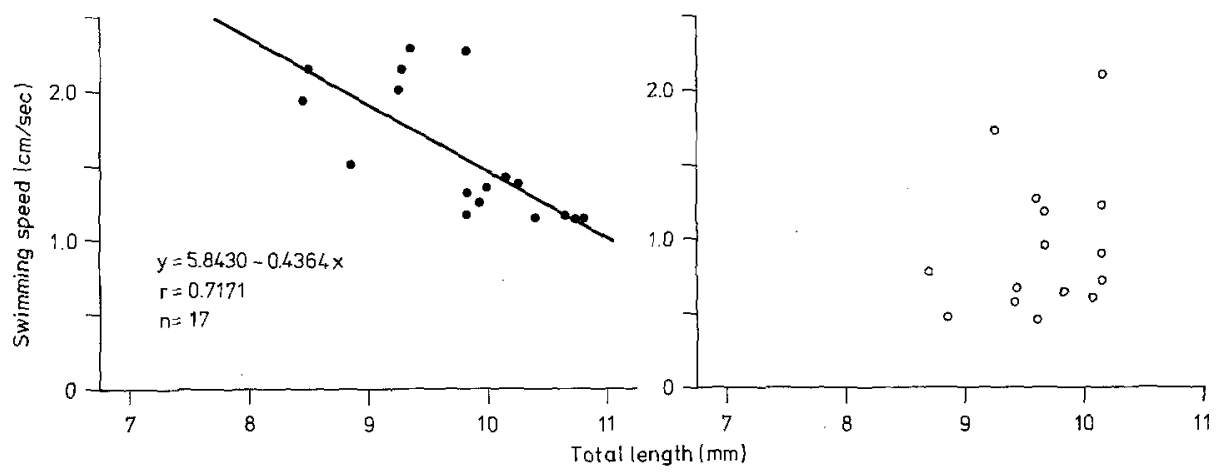

Fig. 4: Swimming speed of naturally spawned and hatched ('wild") (•) and laboratory reared (o) Pacific herring larvae observed in the laboratory in black circular tanks; $\varnothing 35 \mathrm{~cm}$; water depth: $11 \mathrm{~cm} ; 9.5^{\circ} \mathrm{C}$

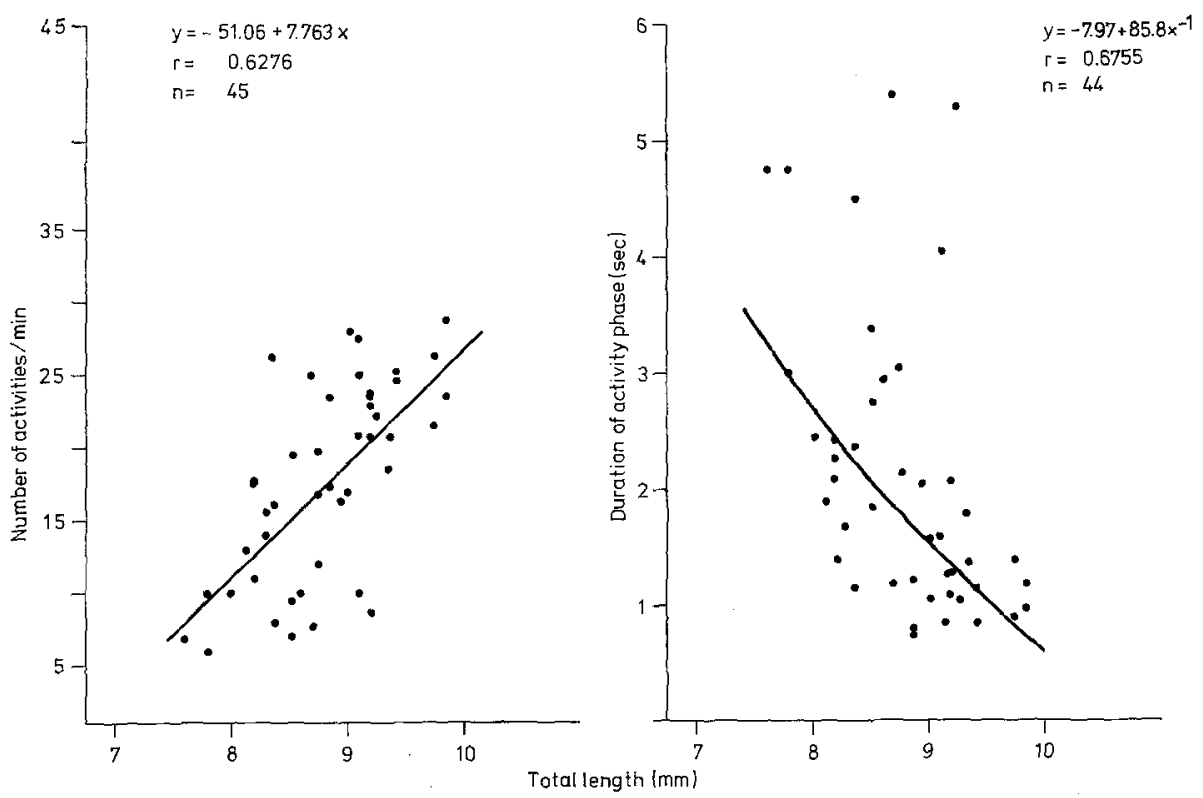

Fig. 5: Relation between total length, number of activities (swimming bursts $/ \mathrm{min}$ ) and duration of swimming phases of Pacific herring larvae in the natural habitat at $9.5^{\circ} \mathrm{C}$

0.5 to $3.0 \mathrm{~cm} / \mathrm{sec}$ (with a mean of $\mathrm{x}=1.6$ ) at $9.5^{\circ} \mathrm{C}$ surface temperature. There was no indication that it increased with larval growth $\left(r_{100}=0.17, \mathrm{P}>0.05\right)$ at least not within the range of larvae we observed $(7.4-12.5 \mathrm{~mm} \mathrm{TL})$ and which was detectable with the observation technique employed. The fact that larvae could maintain much higher swimming speed over several minutes could be shown when the larvae-attracting light was moved and the larvae followed the light. Mean swimming speed during this operation was $2.7 \mathrm{~cm} / \mathrm{sec}$ for $10.5 \mathrm{~mm}$ larvae and $4.3 \mathrm{~cm} / \mathrm{sec}$ for $13.5 \mathrm{~mm}$ larvae.

When comparing the data from the natural habitat with results obtained in the laboratory (Fig. 4), we see that although the mean cruising speed of the "wild" larvae in the 
laboratory was identical to that maintained in the open waters (mean: $1.6 \mathrm{~cm} / \mathrm{sec}$ ), there was a negative correlation between larval length and swimming speed $(y=5.84-0.44 x$; $\left.r_{17}=-0.72, P<0.01\right)$.

From the few observations available laboratory-reared larvae did not show any correlation between total length and cruising speed within the size range observed, but mean swimming velocity was lower than in "wild" larvae (mean: $0.9 \mathrm{~cm} / \mathrm{sec}$ ).

While swimming velocity in the natural habitat remained fairly constant with length (age), the number of swimming bursts/min conducted by larvae in their natural habitat increased with length (age) (Fig. 5, $y=-51.06+7.763 x ; r_{45}=0.63, P<0.01$ ); yet the duration of single swimming bursts became shorter $\left(\mathrm{y}=11.5-1.065 \mathrm{x} ; \mathrm{r}_{44}=-0.47 ; \mathrm{P}<0.01\right)$.

Under laboratory conditions a correlation between activities of the larvae and their age is not readily detectable with the data available. The mean number of activities $/ \mathrm{min}$ (19 swimming bursts/min) in wild larvae (TL $7.4-10.5 \mathrm{~mm}$ ) is smaller than observed in laboratory-reared larvae (TL $8.4-10.3 \mathrm{~mm}$ ) under the same experimental conditions (number of swimming bursts/min: 26). Similarly - although for the total length range of 7.5 to $11.0 \mathrm{~mm}$ no correlation between length (age) and active time was detectable - the mean total active time of "wild" Pacific herring larvae (yolk sac) observed under natural conditions was much higher (50\% of the observation period of $3 \mathrm{~min}$ ) than in the laboratory ( $39 \%$ of the observation period of $3 \mathrm{~min}$ ). Mean total active time of laboratoryreared and observed yolk-sac larvae of similar total length $(9.55 \pm 0.47 \mathrm{~mm})$ was considerably less (30\%).

\section{DISCUSSION}

When considering growth of larvae in and around Departure Bay we are making the assumption that the larvae investigated had been retained within a relatively confined water body for the duration of the experiments. We have no evidence for this assumption, but similar situations have been shown to exist in the retention of larval herring in the Sheepscot estuary of Maine (Graham, 1972).

\section{Growth}

Taking into account the average daily growth of Pacific herring larvae from Departure Bay $(0.46 \mathrm{~mm})$ and a mean size at hatching at about $25 \% \mathrm{~S}$ and $9{ }^{\circ} \mathrm{C}$ of $7.89-8.53 \mathrm{~mm}$ (Alderdice \& Velsen, 1971), we can assume that the yolk-sac larvae caught on April 12th were roughly 2 days old. The larvae caught on April 15th and 16th were younger and part of the catch might have been newly hatched (see Fig. 1a). Thus with progressing time the larval population passing our sampling point with the current consisted at first of individuals derived from distinct spawnings or hatchings, but later in the month and in May the populations became mixed (see Tibbo et al., 1958) and gave rise to polymodal frequency distribution depicted in Fig. 1. This phenomenon is typical for larval populations derived from multiple spawnings and has been described for the spring herring stock spawning in the Kiel Canal connecting the Baltic with the North Sea (Brandhorst, 1956). The possibility of distinguishing between larvae from different spawnings has already been pointed out by McHugh (1940) for Departure Bay herring and Stevenson (1962) and 
Barraclough (1967) for other British Columbia herring populations, and has been practised by Ellertsen et al. (1975) experimenting with larvae of North Sea herring which had hatched in a large outdoor tank.

Comparing daily growth rates of larvae we noted great variations depending on water temperature. While we calculated daily growth of roughly $0.46 \mathrm{~mm}$, McHugh's (1939) data for Departure Bay larvae (as taken from a graph) indicate only about $0.13 \mathrm{~mm}$ growth per day.

Growth of herring larvae in Barkley Sound (Vancouver Island, SE-side) varied from between $0.3 \mathrm{~mm} /$ day for April-hatched and $0.8 \mathrm{~mm} /$ day for May-hatched individuals (Stevenson, 1962) when the water was warmer. Other reports on growth of early herring larvae from the Atlantic are well within the range of our observations. Marshall et al. (1937) reported daily growth rates of $0.46 \mathrm{~mm}$ for Clyde herring (at $7^{\circ} \mathrm{C}$ ) while Kattegat larvae only grew around $0.2 \mathrm{~mm} /$ day at temperatures form 2.0 to $4.7^{\circ} \mathrm{C}$ (Jensen, 1950). Length increments of $0.29 \mathrm{~mm} /$ day at $11{ }^{\circ} \mathrm{C}$ were registered by $\mathrm{Das}$ (1972) for herring larvae from the Bay of Fundy. Schnack (19خ1) determined growth rates of 0.35 to $0.55 \mathrm{~mm} /$ day for Baltic herring larvae. In addition to temperature and food supply growth was to a large extent determined by the developmental stage of the larvae, which would imply that growth did not increase linearly; yet this we can assume in the larvae investigated by us (cf. Fig. 1b).

\section{Condition factor}

As for growth, change of condition factor (weight/length ${ }^{3} \cdot 100$ ) is very similar to that observed earlier in North Sea herring (Hempel \& Blaxter 1963; Blaxter 1971; Vilela \& Zijlstra, 1971). Not only is the pattern of the change of condition factor the same (decrease in yolk-sac larvae and slow increase when feeding starts), but values for condition factors at certain lengths are almost identical when using Vilela \& Zijlstra's (1971) data up to $15 \mathrm{~mm}$. Above $15.0 \mathrm{~mm}$ for North Sea herring an exponential increase in condition factor is noted, while up to the length we investigated $(26.0 \mathrm{~mm})$ increase was linear and fairly slow. When comparing the data of Vilela \& Zijlstra (1971) with values given by Blaxter (1971) we find that figures published by the former authors are up to two times higher than found by Blaxter (1971), while the condition factors we measured for larvae longer than $15.0 \mathrm{~mm}$ were intermediate. Figure 3 shows that at a given length condition factors vary greatly; this may not reflect the actual condition of the larvae but rather be due to whether or not the larvae had recently fed and had retained undigested food organisms in the gut as we have frequently observed. Because larvae feed less at night (Bainbridge \& Forsyth, 1971) and not at all in darkness (Rosenthal \& Hempel, 1970), non-feeding 'night' larvae might have a lower condition factor than feeding 'day' larvae, which could partially explain differences in condition factors between our observations and those of Vilela and Zijlstra (1971).

\section{Swimming speed and performance}

Due to the fact that only the younger stages of the herring larvae swam at or just below the surface during the day, an observation also made by Bridger (1956), the range of total length of larvae used for swimming-performance observations is smaller than the 
range of specimens caught for growth measurement at night. When comparing swimming speed of 'wild' larvae in their natural habitat and in the laboratory, we notice that within the size range observed larger larvae in the sea swam slightly faster (not significant) than smaller ones, but in captivity the larger larvae swam considerably more slowly. Laboratory reared larvae kept under the same condition in the laboratory as wild larvae cruised even more slowly. When investigating swimming speed in herring larvae we have to consider the experiments conducted at $10^{\circ} \mathrm{C}$ by Rosenthal (1968), who classified swimming behaviour of herring larvae. He distinguished between three different kinds of swimming: (1) short bursts $(0.2-0.5 \mathrm{sec}),(2)$ 'normal' swimming $(>0.5 \mathrm{sec})$ and (3) searching. The swimming behaviour we observed and have referred to is 'normal' swimming (Fig. 5); all swimming phases lasted for more than $0.5 \mathrm{sec}$.

Mean swimming speed for 'normal' swimming of laboratory-reared larvae (Fig. 4) for 8.5 to $10.0 \mathrm{~mm}$ specimens was $0.9 \mathrm{~cm} / \mathrm{sec}$, a value similar to that found by Bishai (1959 and Rosenthal (1968) at $10^{\circ} \mathrm{C}$ for laboratory-reared and observed larvae of $6.5-8.0$ and $8.0-11.0 \mathrm{~mm}$ total length $(0.58-1.03 ; 0.8 \mathrm{~cm} / \mathrm{sec})$. In the experiments described by Blaxter and Staines (1971) a value of about $0.5 \mathrm{~cm} / \mathrm{sec}$ at $8-12{ }^{\circ} \mathrm{C}$ (based on a $40 \%$ activity time of the larvae) as swimming speed for 5-10 day old laboratory-reared herring larvae was found. In our observations 'wild' larvae maintained a much higher pace; the mean in the natural habitat $(1.6 \mathrm{~cm} / \mathrm{sec})$ was well above laboratory observations.

When comparing the activities of wild larvae (measured as number of swimming bursts/min) with total length, we noticed that activities increased with length, a fact described by Rosenthal (1968) and Blaxter \& Staines (1971) for laboratory larvae, but the duration of the active phases decreased (Fig. 5). This is the characteristic swimming behaviour of the 8.0 to $10.0 \mathrm{~mm}$ larvae, i. e. long periods of swimming $(2$ to $3 \mathrm{sec}$ ) with long breaks in the yolk-sac larvae, and comparatively short (1 sec) bursts interspaced with short breaks in the late yolk-sac larvae or early post yolk-sac specimens. These short bursts are still much longer than the activities exerted by laboratory larvae. The number of activities of laboratory-reared larvae $(\bar{x}=28.3)$ was considerably higher than observed in 'wild' larvae under natural conditions $(\bar{x}=19.1)$. At the same time the $\%$ active time of 'wild' larvae in nature was higher $(50 \%$ ) than in these larvae observed in the laboratory, which was $39 \%$, a value that compares well with the $35 \%$ active time of laboratory larvae observed by Rosenthal (1968) and a mean value of about $40 \%$ for 9-day old larvae as found by Blaxter \& Staines (1971).

This phenomenon can be explained by the relatively short duration of the swimming activities of laboratory larvae which due to their sinking (Rosenthal, 1968) have to initiate a swimming activity (thus the high number of activities), but possibly due to lack of stimulus fail to continue swimming. The sensory depriving effect of the laboratory environment is clearly shown in Table 1 where one sees that freshly introduced 'wild' larvae still maintained their natural activity in the experiment, but after two days in confinement showed reactions equal to those observed in laboratory-reared specimens.

In this context Blaxter (1970) in his essay on sensory deprivation and sensory input described experiments with herring larvae where tank-reared larvae which were subjected to additional light and current stimuli compared with controls showed a more homogeneous distribution in the experimental tanks, probably due to increased activity of the single individual. 
Thus the differences in swimming speed of herring larvae found by Blaxter \& Staines (1971) $\left(8-12{ }^{\circ} \mathrm{C}, 0.5 \mathrm{~cm} / \mathrm{sec}\right)$ in the laboratory and our observations $(1.6 \mathrm{~cm} / \mathrm{sec})$ in situ might be reconcilable on this basis. Aside from the fact that Blaxter \& Staines' experiments were conducted with Atlantic herring, which may dispiay different activities compared with Pacific individuals, the experimental containers per se might have had a depressing effect on larval activity and swimming speed.

From the above, we can deduct that values gained for swimming velocities and activity of herring larvae in the laboratory appear to be estimated about $50 \%$ (for swimming speed) and $20 \%$ ( $\%$ active time) too low, a fact that might have some bearing on the evaluation of fish larval behaviour in controlled ecosystem experiments, although the amount of stimuli available in an artificial ecosystem can be considered far greater than in an artificially deprived laboratory-scale experiment.

Acknoweledgements. We are indebted to Dr. D. F. Alderdice and Dr. A. S. Hourston, who provided us with laboratory space and other facilities to conduct the experiments, to Dr. T. R. Rao who made the necessary dry weight determinations, and to G. Fürstenberg and J. Klinckmann for expert technical assistance. The work was financially sponsored by the Gesellschaft für Kernenergieverwertung in Schiffbau und Schiffahrt (GKSS) under the Canadian-German ágreement on scientific cooperation.

\section{LITERATURE CITED}

Alderdice, D. F. \& Velsen, F. P. J., 1971. Some effects of salinity and temperature on early development of Pacific herring (Clupea pallasi). J. Fish. Res. Bd Can. 28, 1545-1562.

Bainbridge, V. \& Forsyth, D. C. T., 1971. The feeding of herring larvae in the Clyde. Rapp. P.-v. Réun. Cons. perm. int. Explor. Mer 160, 104-113.

Barraclough, W. E., 1967. Occurrence of larval herring (Clupea pallasii) in the Strait of Georgia during July 1966. J. Fish. Res. Bd Can. 24, 2455-2460.

Bishai, H. M., 1959. The effect of water currents on the survival and distribution of fish larvae. J. Cons. int. Explor. Mer 25, 134-146.

Blaxter, J. H. S., 1970. Sensory deprivation and sensory input in rearing experiments. Helgoländer wiss. Meeresunters. 20, 642-654.

- 1971. Feeding and condition of Clyde herring larvae. Rapp. P.-v. Réun. Cons. perm. int. Explor. Mer 160, 128-136.

- \& Staines, M. E., 1971. Food searching potential in marine fish larvae. Fourth European marine biology symposium. Ed. by D. J. Crisp. Univ. Press, Cambridge, 467-485.

Brandhorst, W., 1956. Uber Laichen und Aufwuchs des Frühjahrsherings im Nord-Ostsee-Kanal. Kieler Meeresforsch. 12, 186-199.

Bridger, J. P., 1956. On day and night variations in catches of fish larvae. J. Cons. perm. int. Explor. Mer 22, 42-57.

Bückmann, A., Harder, W. and Hempel, G., 1953. Unsere Beobachtungen am Hering (Clupea barengus L.). Kurze Mitt. fischereibiol. Abt. Max-Planck-Inst. Wilhelmshaven 3, $22-42$.

Das, N., 1972. Growth of larval herring (Clupea harengus) in the Bay of Fundy and Gulf of Maine area. J. Fish. Res. Bd Can. 29, 573-575.

Ellertsen, B., Solemdahl, P., Tilseth, S. \& Øiestad, V., 1975. A study on survival and growth of fish larvae in a large basin, related to feeding conditions. A preliminary study on herring larvae (Clupea harengus L.) and fry. C.M.-I.C.E.S., E: 44, 1-18.

Graham, J. J., 1972. Retention of larval herring within the Sheepscot estuary of Maine. Fish. Bull. U.S. 70, 299-305.

Harding, J. P., 1949. The use of probability paper for the graphical analysis of polymodal frequency distribution. J. mar. biol. Ass. U. K. 28, 141-153. 
Hempel, G. \& Blaxter, J. H. S., 1963. On the condition of herring larvae. Rapp. P.-v. Réun. Cons. perm. int. Explor. Mer 154, 35-40.

Hourston, A. S., 1958. Population studies on juvenile herring in Barkley Sound, British Columbia. J. Fish. Res. Bd Can. 15, 909-960.

Jensen, A. J. C., 1950. Amount of growth of herring fry in Danish waters. Rep. Dan. biol. Stn. 51, 20-48.

Marshall, S. M., Nicholls, A. G. \& Orr, A. P., 1937. On the growth and feeding of larval stages of the Clyde herring. J. mar. biol. Ass. U. K. 22, 245-267.

McHugh, J. L., 1940. Growth of young herring in Departure Bay in 1939. Progr. Rep. Pacif. biol. Stn. Nanaimo 43, 6-7.

Rosenthal, H., 1968. Schwimmverhalten und Schwimmgeschwindigkeit bei Larven des Herings Clupea barengus. Helgoländer wiss. Meeresunters. 18, 453-486.

— \& Hempel, G., 1970. Experimental studies in feeding and food requirements of herring larvae (Clupea harengus L.). In: Marine food chains. Ed. by J. H. Steele. Oliver \& Boyd, Edinburgh, 344-364.

Schnack, D., 1972. Nahrungsökologische Untersuchungen an Heringslarven. Ber. dt. wiss. Kommn Meeresforsch. 22, 273-343.

Stevenson, J. C., 1962. Distribution and survival of herring larvae (Clupea pallasii Valenciennes) in British Columbia waters. J. Fish. Res. Bd Can. 19, 735-810.

Tibbo, S. N., Legaré, J. E. H., Scattergood, L. M. \& Temple, R. F., 1958. On the occurrence and distribution of larval herring (Clupea barengus L.) in the Bay of Fundy and the Gulf of Maine. J. Fish. Res. Bd Can. 15, 1451-1469.

Titmus, G., Claridge, P. N. \& Potter, I. C., 1978. Growth and abundance of O-group herrings, Clupea harengus L., in the Severn Estuary. Zool. J. Linn. Soc. 64, 251-260.

Vilela, M. H. \& Zijlstra, J. J., 1971. On the condition of herring larvae in the central and southern North Sea. Rapp. P.-v. Réun. Cons. perm. int. Explor. Mer 160, 137-141.

Westernhagen, H. von, 1976. Some aspects of the biology of the hyperiid amphipod Hyperoche medusarum. Helgoländer wiss. Meeresunters, 28, 43-50. 